\title{
Management, nutrition, and lactation performance are related to bulk tank milk de novo fatty acid concentration on northeastern US dairy farms
}

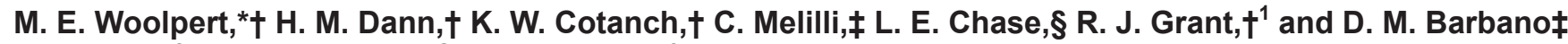 \\ ${ }^{*}$ Department of Animal and Veterinary Science, University of Vermont, Burlington 05405 \\ †William H. Miner Agricultural Research Institute, Chazy, NY 12921 \\ fDepartment of Food Science, and \\ §Department of Animal Science, Cornell University, Ithaca, NY 14853
}

\begin{abstract}
This study investigated the relationship of management practices, dietary characteristics, milk composition, and lactation performance with de novo fatty acid (FA) concentration in bulk tank milk from commercial dairy farms with Holstein, Jersey, and mixed-breed cows. It was hypothesized that farms with higher de novo milk FA concentrations would more commonly use management and nutrition practices known to optimize ruminal conditions that enhance de novo synthesis of milk FA. Farms $(\mathrm{n}=44)$ located in Vermont and northeastern New York were selected based on a history of high de novo (HDN; $26.18 \pm 0.94 \mathrm{~g} / 100 \mathrm{~g}$ of FA; mean \pm standard deviation) or low de novo (LDN; $24.19 \pm$ $1.22 \mathrm{~g} / 100 \mathrm{~g}$ of FA) FA in bulk tank milk. Management practices were assessed during one visit to each farm in March or April, 2014. Total mixed ration samples were collected and analyzed for chemical composition using near infrared spectroscopy. We found no differences in days in milk at the farm level. Yield of milk fat, true protein, and de novo FA per cow per day were higher for HDN versus LDN farms. The HDN farms had lower freestall stocking density (cows/stall) than LDN farms. Additionally, tiestall feeding frequency was higher for HDN than LDN farms. No differences between HDN and LDN farms were detected for dietary dry matter, crude protein, neutral detergent fiber, starch, or percentage of forage in the diet. However, dietary ether extract was lower for HDN than LDN farms. This research indicates that overcrowded freestalls, reduced feeding frequency, and greater dietary ether extract content are associated with lower de novo FA synthesis and reduced milk fat and true protein yields on commercial dairy farms.
\end{abstract}

Key words: de novo fatty acid, feeding management, milk fat, stocking density, true protein

Received February 8, 2016.

Accepted June 28, 2016.

${ }^{1}$ Corresponding author: grant@whminer.com

\section{INTRODUCTION}

Milk fat and true protein content are primary drivers of income over feed cost on commercial dairy farms (Bailey et al., 2005). In bulk tank milk samples taken 3 to 20 times per month on 430 commercial farms for 15 mo, Barbano et al. (2014) identified a positive correlation between de novo milk fatty acids (FA; C4 to C14) concentration and milk fat and true protein content. Consequently, identifying management and dietary factors that are related to milk de novo FA concentration may be useful for making recommendations to dairy producers to increase bulk tank milk fat and protein content and improve the income over feed cost of dairy farms.

For high-producing Holstein cows, de novo FA typically account for 18 to $28 \%$ of the total FA in milk fat (Jensen, 2002). Milk FA profiles vary due to animal factors such as breed and genetics (Soyeurt et al., 2006) and stage of lactation (Lynch et al., 1992; Stoop et al., 2009). In addition, nutritional and management practices may influence milk FA profiles and are the predominant environmental factors that affect milk de novo FA synthesis among cows of similar breed and stage of lactation (Palmquist et al., 1993; Bauman and Griinari, 2003).

Diets high in fermentable carbohydrates and PUFA may result in depressed milk fat through a shift toward the so-called alternate rumen biohydrogenation pathway, leading to the formation of FA isomers, which downregulate the expression of genes related to de novo FA synthesis (Harvatine and Bauman, 2011). Dietary fat supplementation may also influence milk fat composition by directly providing substrate for preformed milk FA (Stoffel et al., 2015), although the extent of variation is limited by the melting point of the milk fat globule (Toral et al., 2013). In addition, management practices that change feeding behavior, such as overstocking of the feed bunk (Sova et al., 2013), may increase a cow's risk for low ruminal $\mathrm{pH}$ (French and Kennelly, 1990) and lead to a reduction in milk fat content (Allen, 1997). Consequently, bulk tank milk de 
novo FA content may serve as an indicator of ruminal fermentation conditions that prevail within the herd.

Most previous research has evaluated the effects of just one, or a small number, of dietary and management factors on individual cow milk FA profiles and has been reviewed elsewhere (Grummer, 1991; Palmquist et al., 1993; Neville and Picciano, 1997; Harvatine et al., 2009). These controlled experiments have been crucial to understanding the factors that affect milk de novo FA content. On a bulk tank basis, Coppa et al. (2013) predicted FA composition using data that described the source and proportion of forages in the diet. However, further research is still needed to describe the relationship of farm management practices and dietary chemical composition with bulk tank de novo FA content on commercial dairy farms. A goal of this type of research is to assess the value of using bulk tank milk FA composition as a herd management tool in addition to individual cow milk FA.

Therefore, the objective of the current study was to understand the relationship of farm management, dietary composition, milk composition, and lactation performance with milk de novo FA content and yield in bulk tank milk from commercial dairy farms in Vermont and northeastern New York State. We hypothesized that bulk tank milk from farms that more commonly use management practices and dietary strategies known to optimize ruminal conditions will produce milk with higher de novo FA content.

\section{MATERIALS AND METHODS}

\section{On-Farm Data Collection}

Commercial dairy farms $(\mathrm{n}=44)$ located in Vermont and northeastern New York State were enrolled in the study. Eligible farms were members of the St. Albans Cooperative Creamery (St. Albans, VT). Farms were categorized as high de novo $(\mathbf{H D N} ; 26.18 \pm 0.94 \mathrm{~g} / 100$ $\mathrm{g}$ of $\mathrm{FA}$; mean $\pm \mathrm{SD})$ or low de novo $(\mathbf{L D N} ; 24.19$ $\pm 1.22 \mathrm{~g} / 100 \mathrm{~g}$ of FA) based on the mean bulk tank milk de novo FA concentration from September 2013 to February 2014 (Table 1). All farms in the St. Albans Cooperative were ranked from high to low for de novo FA (expressed as FA/100 g of FA) for the 6 mo before the study. Farms were identified by the St. Albans Cooperative as predominantly Holstein or predominantly Jersey farms. The objective was to visit $20 \mathrm{HDN}$ and 20 LDN farms; however, additional farms were contacted because some farms $(n=12)$ were not interested in participating in the study or were unable to be contacted by phone. Ultimately, $21 \mathrm{HDN}$ farms and 23 LDN farms were visited once between March 21, 2014, and April 30, 2014, and all farms were included in the final data set.

During each farm visit, trained research personnel worked with a farm owner or manager to complete a questionnaire. Breed of cows on the farm was self-reported by the farm owner or manager and classified as percentage of the farm that was Holsteins. The number of cows milking and average bulk tank milk shipped for the month of the farm visit was used to determine the mean milk yield per cow. Frequency of fresh feed delivery, number of lactating groups housed separately, and number of nutritional groups (defined as the number of lactating groups fed a unique diet) were included in the questionnaire. Farm DIM was sourced from either a test day within one month of the farm visit by the DHIA (Vermont DHIA, White River Junction, VT) or Dairy One (Ithaca, NY) or by computer dairy-management software (PC Dart, Dairy Records Management Services, Raleigh, NC; Dairy Comp 305, Valley Ag Software,

Table 1. Milk composition data representing monthly mean milk composition by farm from September 2013 to February 2014 that was used to select high de novo (HDN) and low de novo (LDN) farms to participate in the study

\begin{tabular}{|c|c|c|c|c|c|c|}
\hline \multirow[b]{2}{*}{ Milk component } & \multicolumn{3}{|c|}{$\mathrm{HDN}$} & \multicolumn{3}{|c|}{$\mathrm{LDN}$} \\
\hline & Mean $\pm \mathrm{SD}$ & Minimum & Maximum & Mean $\pm \mathrm{SD}$ & Minimum & Maximum \\
\hline True protein, $\%$ & $3.50 \pm 0.29$ & 3.11 & 4.08 & $3.16 \pm 0.17$ & 2.90 & 3.45 \\
\hline \multicolumn{7}{|l|}{ De novo fatty acids ${ }^{1}$} \\
\hline $\mathrm{g} / 100 \mathrm{~g}$ of milk & $1.13 \pm 0.16$ & 0.88 & 1.40 & $0.90 \pm 0.08$ & 0.80 & 1.08 \\
\hline $\mathrm{g} / 100 \mathrm{~g}$ of fatty acids & $26.18 \pm 0.94$ & 24.20 & 28.00 & $24.19 \pm 1.22$ & 21.70 & 26.03 \\
\hline $\mathrm{g} / 100 \mathrm{~g}$ of fatty acids & $38.24 \pm 0.98$ & 35.65 & 39.80 & $36.85 \pm 1.44$ & 32.18 & 38.73 \\
\hline \multicolumn{7}{|l|}{ Preformed fatty acids ${ }^{3}$} \\
\hline $\mathrm{g} / 100 \mathrm{~g}$ of milk & $1.52 \pm 0.14$ & 1.31 & 1.75 & $1.43 \pm 0.09$ & 1.33 & 1.70 \\
\hline $\mathrm{g} / 100 \mathrm{~g}$ of fatty acids & $35.58 \pm 1.41$ & 33.24 & 38.01 & $38.80 \pm 2.09$ & 35.94 & 45.82 \\
\hline
\end{tabular}

${ }^{1} \mathrm{C} 4$ to $\mathrm{C} 14$.

${ }^{2} \mathrm{C} 16, \mathrm{C} 16: 1$, and $\mathrm{C}: 17$.

${ }^{3}$ Greater than or equal to C18. 
Tulare, CA). Bunk space (linear feed bunk space per cow in the pen) and stall stocking density (number of cows per freestall in the pen) were determined during each farm visit on a per-pen basis for freestall farms only. Body condition score on a 1 - to 5 -scale at 0.25 increments (Ferguson et al., 1994) was determined during each farm visit on a pen basis. At least 10 animals or $10 \%$ of the group were assigned a BCS. A weighted average of each pen's stocking density, bunk space, and BCS was calculated based on the number of cows in a pen to determine the mean stocking density, bunk space, and BCS on a farm basis.

Forage and TMR samples were collected on each farm and placed into a resealable plastic bag $(30.5 \times$ $38 \mathrm{~cm})$ at the time of the farm visit. Total mixed rations were sampled from 5 to 10 locations along the length of the feed bunk for all lactating groups of cows. Forage samples from bunker silos or silo bags (Ag Bags; Miller-St. Nazianz Inc., St. Nazianz, WI) were collected from 5 to 10 locations on the bunk face. Forages stored in upright silos were unloaded into a cart, homogenized manually, and subsampled using the quartering technique: homogeneous samples were divided into 4 equal subsamples. Then, 2 subsamples allocated diagonally were rehomogenized and saved. Round bales and square bales were sampled using a core sampler (Star Quality Samplers, Edmonton, Alberta, Canada) with at least 2 samples taken from opposite sides of a round bale or ends of a square bale.

A 500-g subsample of forage and TMR was taken by placing the sample in a tub, manually homogenizing, and subsampling using the quartering technique as previously described. Subsamples were dried in a forced-air oven at $60^{\circ} \mathrm{C}$ for $4 \mathrm{~h}$, ground to $1 \mathrm{~mm}$ using a Udy Cyclone mill (Udy Corporation, Ft. Collins, $\mathrm{CO}$ ), and analyzed for chemical composition using near infrared spectroscopy (NIRS) in a commercial laboratory (Dairy One; Shenk and Westerhaus, 1991; FOSS NIR Systems Model 6500 with Win ISI II v1.5 software, Foss-NIR System, Silver Spring, MD).

Hay crop silages, corn silages, and TMR were analyzed for DM (method 991.01; AOAC International, 2012), CP (method 989.03; AOAC International, 2012), and ADF (method 989.03; AOAC International, 2012). Neutral detergent fiber, ether extract, ash, and starch calibrations were developed for NIRS according to AOAC International (2012) method 989.03. Near infrared calibrations were based on reference chemistry using traditional procedures for aNDF with $\alpha$-amylase and sodium sulfite (method 2002.04; AOAC International, 2012), ether extract (method 2003.05; AOAC International, 2012), and ash (method 942.05; AOAC International, 2012). Near infrared calibrations for starch were developed based on methods described by Bach Knudsen (1997) using a YSI 2700 SELECT Biochemistry Analyzer (YSI Inc. Life Sciences, Yellow Springs, OH).

In the case of a farm with more than 1 lactating cow diet, TMR analyses were mathematically composited by the number of cows consuming the diet. All farms that fed corn silage were only feeding 1 source of corn silage at the day of the visit, but several farms were feeding multiple sources of hay crop silage $(\mathrm{n}=15)$. Dietary ingredient composition was requested from herd nutritionists for all farms; however, it was only provided by the nutritionists for 34 farms. When available, dietary composition from farms feeding multiple hay crop silage sources ( $\mathrm{n}=6$ farms) was used to calculate a weighted average based on the number of cows consuming the diets and the proportion of each hay crop silage source (on a DM basis) in each diet. When dietary information was not available ( $\mathrm{n}=9$ farms), hay crop silage analyses were averaged for each farm. Five farms did not feed hay crop silage.

\section{Supplemental Feed Products}

Feed supply companies provided the ingredients for concentrate feeds included in all diets fed to lactating cows on each farm. One farm did not feed any concentrates, and concentrate ingredient information was not available for 10 farms; therefore, supplemental feeds were analyzed for 33 farms. Feed products analyzed were selected because of their previously reported association with changes in milk fat content or composition and categorized as distillers grains (Schingoethe et al., 2009), monensin (Rumensin, Elanco Animal Health, Indianapolis, IN; Duffield et al., 2008), rumen-inert fat (Loften et al., 2014), animal-derived fat (Onetti et al., 2003), yeast (Desnoyers et al., 2009), and EAA sources (Zanton et al., 2014) such as animal-derived protein and commercial AA (rumen-protected lysine or methionine). If a farm fed a product to at least one dietary group it was included in the analysis. Forageto-concentrate ratios on a DM basis were calculated based on dietary specifications reported by the farm's nutrition consultant.

\section{Milk Yield and Composition}

Milk yield was calculated using the number of cows milking during the farm visit and the average bulk tank milk shipped during the month of the farm visit. Milk composition data were averaged for the month of the farm visit (March or April, 2014). Milk fat, true protein, and anhydrous lactose content were determined using a Fourier transform mid-infrared (FTIR) spectrophotometer (Lactoscope FTA, Delta Instru- 
Table 2. Number of samples, mean of reference value, SD, minimum and maximum values of final population of samples (i.e., with outliers removed) used to develop mid-Fourier transform infrared (mid-FTIR), partial least squares (PLS) prediction models ${ }^{1}$

\begin{tabular}{lcccc}
\hline & & \multicolumn{2}{c}{ Mid-FTIR PLS prediction models } \\
\cline { 2 - 5 } Item & Total fatty acids & De novo fatty acids & Mixed fatty acids & Preformed fatty acids \\
\hline Number of samples & 268 & 268 & 268 & 1.03 \\
Mean & 3.36 & 0.83 & 0.29 & 1.51 \\
SD & 0.9 & 0.26 & 0.06 & 0.41 \\
Minimum & 0.19 & 0.05 & 9 & 0.08 \\
Maximum & 6.15 & 1.82 & 0.047 & 11 \\
Number of factors & 8 & 0.025 & 0.056 \\
SECV & 0.019 & 0.991 & 0.975 & 0.981 \\
R & 0.999 & 1.272 & 1.165 & 0.893 \\
F-Ratio (PRESS) & 1.1623 & 0.975 & 6.2 & 0.792 \\
F-Test (FPRESS) & 0.8894 & 10.4 & 7.3 \\
RPD & 47.6 & & \\
\hline
\end{tabular}

${ }^{1}$ Number of factors, standard error of cross validation (SECV), $R^{2}$, F-ratio predicted residual sum of squares (PRESS), F-test (FPRESS), and the ratio of standard deviation to standard error of cross validation (RPD) of the calibration step for the PLS model to predict total, de novo, mixed origin, and preformed fatty acids in milk expressed as $\mathrm{g} / 100 \mathrm{~g}$ of milk.

ments, Drachten, the Netherlands) at the St. Albans Cooperative Creamery payment testing laboratory (St. Albans, VT). Calibration of the FTIR for measurement of fat, true protein, and anhydrous lactose was done using modified milk calibration samples (Kaylegian et al., 2006) produced monthly with all-laboratory mean reference chemistry values produced by a network of 10 to 12 laboratories (Wojciechowski et al., 2016). The reference methods for fat, true protein, and anhydrous lactose measurement were determined in duplicate in each laboratory using the following validated methods (AOAC International, 2000): fat by modified Mojonnier ether extraction (method 989.05), true protein by Kjeldahl analysis (method 991.22), and lactose by enzymatic analysis (method 2006.06). The slopes and intercepts were checked and adjusted every 2 wk.

Milk FA analyses were conducted with FTIR using a Delta Instruments FTA (Delta Instruments) at the St. Albans Cooperative payment testing laboratory simultaneously with the component milk testing. The models used with this equipment allowed total FA, as well as FA groups (de novo, C4 to $\mathrm{C} 14$; mixed origin, C16:0, C16:1, C17:0; and preformed, $\geq \mathrm{C} 18: 0$ ), to be measured with the FTIR spectrophotometer. The partial least squares (PLS) modeling performance characteristics of the PLS models for total, de novo, mixed, and preformed FA are provided in Table 2. All 4 models had a ratio of standard deviation to standard error of cross validation (RPD) of the calibration $>5$ and coefficient of determination exceeding 0.97 , which is comparable or better than what has been reported in other mid-infrared prediction models for milk FA (Soyeurt et al., 2006, 2011; Maurice-Van Eijndhoven et al., 2013). The models for total and de novo FA had the most robust modeling statistics (i.e., SECV, $\mathrm{R}^{2}$, and
RPD). As reported by Soyeurt et al. (2006), we also found that PLS models for prediction of shorter-chain FA were more robust than other FA predictions. The slopes and intercepts of each PLS model calibration for all milk FA parameters were adjusted with the same 14-sample set of milk calibration samples that was used for calibration of the other major milk components. Reference values for individual and groups of milk FA for the 14-sample calibration set were determined by gas liquid chromatography as described by Lynch et al. (2005) and Kaylegian et al. (2009a,b).

\section{Statistical Analysis}

Statistical analyses were conducted with SAS (version 9.2, SAS Institute Inc., Cary, NC). Data were summarized by HDN or LDN group and checked for normality using the UNIVARIATE procedure. Data were considered to be normally distributed when the Shapiro-Wilks W was greater than 0.85. Because breed is known to affect milk FA composition (Soyeurt et al., 2006), the data were adjusted covariately by the percentage of Holsteins on the farm. The Akaike information criterion (Akaike, 1973) was used for model comparison with and without covariate adjustment. The Akaike information criterion was more highly conserved in the covariate adjusted model; therefore, the adjusted model was used for all milk composition variables and when significant $(P \leq 0.05)$ for management variables (number of cows milking and feed bunkspace). The covariate was not significant $(P>0.10)$ for dietary variables; therefore, the covariate was not included in the model. The magnitude of the covariate adjustment is reported as the parameter estimate for the covariate in the model and was $<0.1$ in all 
cases, with the exception of milk yield and de novo, mixed, and preformed FA yield (Table 3). The effect of breed on FA yield was minimal; a $1 \%$ increase in the percentage of Holsteins on the farm is associated with $0.14 \mathrm{~kg} / \mathrm{d}$ and $0.65,1.26$, and $1.34 \mathrm{~g} / \mathrm{d}$ increases for milk yield and de novo, mixed, and preformed FA, respectively. In addition, the variance explained by the covariate was minimal for management factors but was moderate for milk composition variables. This variance explained by the percentage of Holsteins in the herd was expected, given the previously reported effects of breed on milk yield and composition (Soyeurt et al., 2006) and reinforces the importance of including breed as a covariate in the model.

Differences in management, TMR, and milk composition for HDN versus LDN farms were determined using the GLIMMIX procedure of SAS with de novo group as the fixed effect and farm as the random effect with the following model equation:

$$
\mathrm{Y}_{\mathrm{ijk}}=\mu+\alpha_{\mathrm{i}}+\beta_{\mathrm{j}}+\mathrm{R}_{\mathrm{k}}+\mathrm{E}_{\mathrm{ijk}}
$$

where $Y_{i j k}$ is the dependent variable, $\mu$ is the overall mean, $\alpha_{\mathrm{i}}$ is the fixed effect of de novo group, $\beta_{\mathrm{j}}$ is the fixed effect of the covariate, $R_{k}$ is the random effect of farm, and $E_{\mathrm{ijk}}$ is the residual error. Farms were categorized as HDN or LDN based on mean bulk tank milk de novo FA concentration from September 2013 to February 2014 (Table 1).

A Poisson distribution with a log link function was used to test the number of cows milking on each farm and the number of times feed was pushed up at the feed bunk. The best fit distribution was identified using the chi-squared-to-degrees freedom ratio (Gbur et al., 2012). Optimal model fit results in a chi-squared-todegrees of freedom ratio close to 1.0. Freestall feeding frequency ( 1 or 2 times per day), milking frequency ( 2 or 3 times per day), freestall barn design (4 or 6 rows of stalls), and inclusion of ingredients of interest in the concentrate mix were analyzed with a binary distribution and a logit link function to generate odds ratios and $95 \%$ confidence intervals, using a similar approach as Silva et al. (2014). All other dietary and management variables were normally distributed and were tested with a Gaussian distribution with an identity link function. Differences were declared significant at $P$ $\leq 0.05$ and trends at $0.05<P \leq 0.10$

Two farms had extremely low starch values, either due to sampling error or due to rations that were not balanced to meet the nutrient requirements of lactation. These farms were identified as outliers according to Cook's distance (Cody, 2011) and were removed from the dietary composition data set.
Table 3. Magnitude ${ }^{1}$ of the covariate (percentage of Holsteins) for models where the effect of the covariate was significant $(P<0.05)$

\begin{tabular}{|c|c|c|c|}
\hline Item & Variance $^{2}$ & $\begin{array}{c}\text { Parameter } \\
\text { estimate }\end{array}$ & $P$-value \\
\hline Cows milking, no. & 0.17 & 0.012 & $<0.01$ \\
\hline Bunkspace, $\mathrm{cm} / \mathrm{cow}$ & 0.24 & -0.076 & $<0.01$ \\
\hline Milk, $\mathrm{kg} / \mathrm{d}$ & 0.49 & 0.141 & $<0.01$ \\
\hline Fat, $\mathrm{kg} / \mathrm{d}$ & 0.26 & 0.004 & $<0.01$ \\
\hline Fat, $\%$ & 0.45 & -0.009 & $<0.01$ \\
\hline True protein, $\mathrm{kg} / \mathrm{d}$ & 0.64 & 0.004 & $<0.01$ \\
\hline True protein, \% & 0.34 & -0.004 & $<0.01$ \\
\hline \multicolumn{4}{|l|}{ De novo fatty acids ${ }^{3}$} \\
\hline $\mathrm{g} / 100 \mathrm{~g}$ of milk & 0.43 & -0.003 & $<0.01$ \\
\hline $\mathrm{g} / 100 \mathrm{~g}$ of fatty acids & 0.10 & -0.011 & $<0.01$ \\
\hline $\mathrm{g} / \mathrm{d}$ & 0.16 & 0.654 & $<0.01$ \\
\hline \multicolumn{4}{|l|}{ Mixed fatty acids ${ }^{4}$} \\
\hline $\mathrm{g} / 100 \mathrm{~g}$ of milk & 0.46 & -0.004 & $<0.01$ \\
\hline $\mathrm{g} / 100 \mathrm{~g}$ of fatty acids & 0.01 & -0.002 & 0.61 \\
\hline $\mathrm{g} / \mathrm{d}$ & 0.23 & 1.256 & $<0.01$ \\
\hline \multicolumn{4}{|l|}{ Preformed fatty acids ${ }^{5}$} \\
\hline $\mathrm{g} / 100 \mathrm{~g}$ of milk & 0.65 & -0.003 & $<0.01$ \\
\hline $\mathrm{g} / 100 \mathrm{~g}$ of fatty acids & 0.06 & 0.014 & 0.01 \\
\hline $\mathrm{g} / \mathrm{d}$ & 0.29 & 1.341 & $<0.01$ \\
\hline Anhydrous lactose, $\%$ & 0.12 & $<0.001$ & 0.03 \\
\hline Anhydrous lactose, $\mathrm{kg} / \mathrm{d}$ & 0.48 & 0.015 & $<0.01$ \\
\hline
\end{tabular}

${ }^{1}$ The magnitude is reported as the parameter estimate for the percentage of Holsteins and the variance explained by percentage of Holsteins.

${ }^{2}$ The difference of the $\mathrm{R}^{2}$ of the model including the percentage of Holsteins as the covariate and the model without including the percentage of Holsteins as the covariate.

${ }^{3} \mathrm{C} 4$ to $\mathrm{C} 14$.

${ }^{4} \mathrm{C} 16, \mathrm{C} 16: 1$, and $\mathrm{C}: 17$.

${ }^{5}$ Greater than or equal to $\mathrm{C} 18$.

\section{RESULTS AND DISCUSSION}

\section{Validation of FA Prediction Models}

During the process of selecting the final group of St. Albans Coop farms for the study, a performance validation of the mid-FTIR prediction models was done by FA analysis of bulk tank milk from 20 LDN and 20 HDN farms from the pool of low- and high-de novo farms being considered for use in the study by both the GC reference method and mid-FTIR. The validation of the accuracy of the mid-FTIR methods for use in this study is shown in Table 4.

Total FA predicted by infrared milk analyzer were in excellent agreement (relative $\mathrm{SD}<1.0 \%$ ) with GC measurement of FA for the 40 farms (Table 4). The agreement between GC and FTIR estimates was better for de novo FA than for mixed or preformed FA. The mixed and preformed FA differ in chemical structure by only 2 carbons, essentially $\mathrm{C} 16$ versus $\mathrm{C} 18$. This small difference in FA structure is more challenging for midinfrared to quantify separately, than de novo versus non de novo FA. The current PLS model overestimated mixed-origin FA and underestimated preformed FA on average (Table 4) and should be a focus for im- 
Table 4. Validation comparison of mean difference (MD), standard deviation of the difference (SDD) and relative standard deviation (RSD) of GC measurement of total, de novo, mixed origin, and preformed fatty acids to mid-infrared (IR) partial least square predictions for bulk tank milk samples $(\mathrm{n}=40)$

\begin{tabular}{lcccc}
\hline & \multicolumn{4}{c}{ Fatty acids, $\mathrm{g} / 100 \mathrm{~g}$ of milk } \\
\cline { 2 - 5 } Parameter & Total & De novo & Mixed & Preformed \\
\hline Overall IR mean & 3.769 & 0.928 & 1.258 & 1.583 \\
Overall GC mean & 3.769 & 0.944 & 1.198 & 1.627 \\
MD (IR - GC) & 0.000 & -0.016 & 0.060 & -0.044 \\
SDD & 0.035 & 0.024 & 0.072 & 0.080 \\
RSD, $\%$ & 0.93 & 2.64 & 5.69 & 5.03 \\
\hline
\end{tabular}

provement in future modeling. Overall, the accuracy and repeatability of the estimate of de novo FA was more robust $(\mathrm{RPD}>10)$ than mixed and preformed FA (Table 2), but was less robust than the estimate of total FA (RPD >47). The de novo FA metric of bulk tank milk was used as the key FA parameter to measure the relationship between bulk tank milk fat and protein concentrations and their relationship to de novo milk FA synthesis.

\section{Farm Characterization}

We found similar numbers of tiestall and freestall farms within the HDN and LDN groups (Table 5). On average, a higher percentage of Holstein cows were on farms in the LDN group. Breed has a strong effect on milk fat and protein content (Soyeurt et al., 2006). For this reason it was especially important to include breed as a covariate in the models. Although both conventional and certified organic farms were in the study, farms were visited before the grazing season began. Therefore, all of the cows were consuming an indoor diet on the day of each farm visit.

Table 5. Descriptive statistics (mean \pm SD) characterizing management factors for high de novo (HDN) or low de novo (LDN) farms

\begin{tabular}{lcc}
\hline Item & HDN & LDN \\
\hline Farms, no. & 21 & 23 \\
Holstein, \% of farm & $33.7 \pm 38.5$ & $61.4 \pm 41.2$ \\
Cows milking, no. & $120 \pm 108$ & $224 \pm 274$ \\
Lactating groups, ${ }^{1}$ no. & $1.8 \pm 1.3$ & $2.1 \pm 1.7$ \\
Nutritional groups, ${ }^{2}$ no. & $1.5 \pm 0.8$ & $1.8 \pm 1.3$ \\
Housing type & 13 & 10 \\
Freestall, no. & 4 & 1 \\
2 rows per pen, ${ }^{3}$ no. & 9 & 9 \\
3 rows per pen, ${ }^{3}$ no. & 8 & 13 \\
Tiestall, no. & 14 & 4 \\
Conventional, no. & 9 & \\
Certified organic, no. & & \\
\hline
\end{tabular}

${ }^{1}$ Separately housed groups of lactating cows per farm.

${ }^{2}$ Rations fed to lactating cows per farm.

${ }^{3}$ Indicates the number of rows of stalls per feed bunk in the pen.
The number of milking cows was not different $(P=$ 0.93 ) between HDN and LDN farms, suggesting that farm size was not a significant factor in HDN versus LDN farms, despite the large variation in farm sizes within the HDN and LDN groups (Table 6). Days in milk were not different $(P=0.88)$ between HDN and LDN farms. The FA profile of bovine milk changes substantially throughout a cow's lactation (Lynch et al., 1992); however, because DIM were not different between groups, the stage of lactation of individual cows was not likely to affect the comparison of HDN versus LDN milk composition in the current study. In addition, no difference was observed in milking frequency between HDN and LDN farms, which was either 2 or 3 times per d $(P=0.19$; Table 6$)$.

\section{Milk Composition}

Milk yield tended to be higher for HDN farms $(P=$ 0.06 ; Table 7). Milk fat yield, true protein yield, and true protein content were higher $(P<0.01)$ on HDN farms, whereas milk fat content tended to be higher $(P=0.10)$. These results are consistent with previous research that found that de novo FA content is correlated positively with milk fat and true protein content (Barbano et al., 2014). De novo FA (expressed as g/100 $\mathrm{g}$ of FA, g/100 g of milk, and $\mathrm{g} / \mathrm{d})$ were higher $(P$ $<0.05)$ on HDN farms. This result was by design, as farms were selected to participate in the study based on de novo FA content.

The higher milk fat and protein yields per cow per day for HDN farms would indicate that gross milk income per cow was higher on HDN farms during the period of the study. The difference in income per cow would depend on the actual milk price at any point in time. However, the average fat and protein price for the Federal Milk Order No. 1 for March and April 2014 (USDA, 2014) was $\$ 4.62$ and $\$ 10.17$ per $\mathrm{kg}$, respectively. Therefore, at $25 \mathrm{~kg}$ of milk per cow per day, the average HDN farm earned a gross of $\$ 5.50$ and $\$ 7.72$ per cow for fat and protein, respectively. The average LDN farm at $25 \mathrm{~kg}$ of milk per cow per day earned a 
Table 6. Odds ratio for binary management and dietary data for high de novo (HDN) or low de novo (LDN) farms observed during the farm visit

\begin{tabular}{lcccc}
\hline Item & HDN, $\%$ & LDN, \% & OR $^{1}(95 \%$ CI $)$ & $P$-value \\
\hline Freestall feeding frequency & $50.0^{2}$ & $80.2^{2}$ & $0.25(0.03-2.11)$ & 0.19 \\
Milking frequency & $81.0^{3}$ & $74.0^{3}$ & $1.50(0.33-6.79)$ & 0.59 \\
Freestall barn design & $69.4^{4}$ & $90.0^{4}$ & $0.25(0.02-3.39)$ & 0.28 \\
Component vs. TMR fed & $33.3^{5}$ & $43.5^{5}$ & $0.65(0.18-2.37)$ & 0.50 \\
One vs. multiple lactating TMR fed & $50.0^{6}$ & $38.4^{6}$ & $1.60(0.30-8.63)$ & 0.57 \\
\hline
\end{tabular}

${ }^{1} \mathrm{OR}=$ odds ratio. The HDN group was set as referent.

${ }^{2}$ Percentage of farms feeding once per day.

${ }^{3}$ Percentage of farms milking twice per day.

${ }^{4}$ Percentage of farms with 3 rows of stalls per row of feed bunk in the pen.

${ }^{5}$ Percentage of component-fed farms (forages and grain fed separately).

${ }^{6}$ Percentage of TMR-fed farms feeding only one diet to lactating cows.

gross of $\$ 5.26$ and $\$ 7.29$ per cow for fat and protein, respectively. These differences for fat and protein between HDN and LDN herds at $25 \mathrm{~kg}$ of milk would result in a gross income difference of $\$ 8,544$ for fat and $\$ 15,695$ for protein per 100 milking cows per year.

Mixed FA were higher $(P \leq 0.03)$ in HDN farms (Table 7). About half of the mixed FA originate from de novo synthesis when cows are in positive energy balance (Loften et al., 2014). It is possible that the same mechanism that was driving de novo synthesis for FA shorter than 14 carbons was also driving de novo synthesis of palmitic acid. An alternate explanation may be that HDN farms were feeding more palmitic acid through rumen-inert feed product supplementation. Dietary palmitic acid has been found to increase milk fat content without downregulating de novo synthesis (Loften et al., 2014). No difference was detected in the proportion of farms feeding a rumen-inert fat product $(P>0.10$; Table 8$)$. However, the composition of the rumen-inert fat products fed on farms was not provided to the researchers in the current study. In addition, using the analytical procedures in the present study, it was not possible to differentiate whether the additional mixed FA on HDN farms was of dietary origin or from de novo synthesis.

Preformed FA (expressed as $\mathrm{g} / 100 \mathrm{~g}$ of $\mathrm{FA}$ and as $\mathrm{g} / 100 \mathrm{~g}$ of milk) were lower $(P \leq 0.04$; Table 7$)$ on HDN farms, but there was no detectable difference $(P=0.12)$ in preformed FA yield per day (Table 7$)$. These results suggest that changes in preformed FA

Table 7. Least squares means of milk composition covariately adjusted by the percentage of Holsteins for high de novo (HDN) and low de novo (LDN) farms for the month of the farm visit

\begin{tabular}{|c|c|c|c|c|}
\hline Item & $\mathrm{HDN}$ & $\mathrm{LDN}$ & SEM & $P$-value \\
\hline Milk kg/d & 26.3 & 22.7 & 1.3 & 0.06 \\
\hline Fat, kg/d & 1.1 & 0.9 & 0.1 & 0.01 \\
\hline Fat, $\%$ & 4.33 & 4.14 & 0.08 & 0.10 \\
\hline True protein, $\mathrm{kg} / \mathrm{d}$ & 0.89 & 0.73 & 0.04 & $<0.01$ \\
\hline True protein, \% & 3.41 & 3.22 & 0.04 & $<0.01$ \\
\hline \multicolumn{5}{|l|}{ De novo fatty acids ${ }^{1}$} \\
\hline $\mathrm{g} / 100 \mathrm{~g}$ of milk & 1.06 & 0.94 & 0.02 & $<0.01$ \\
\hline $\mathrm{g} / 100 \mathrm{~g}$ of fatty acids & 25.61 & 23.71 & 0.19 & $<0.01$ \\
\hline $\mathrm{g} / \mathrm{d}$ & 269.8 & 207.3 & 12.9 & $<0.01$ \\
\hline \multicolumn{5}{|l|}{ Mixed fatty acids ${ }^{2}$} \\
\hline $\mathrm{g} / 100 \mathrm{~g}$ of milk & 1.60 & 1.50 & 0.03 & 0.03 \\
\hline $\mathrm{g} / 100 \mathrm{~g}$ of fatty acids & 38.86 & 37.98 & 0.26 & 0.02 \\
\hline $\mathrm{g} / \mathrm{d}$ & 411.9 & 329.7 & 20.0 & $<0.01$ \\
\hline \multicolumn{5}{|l|}{ Preformed fatty acids ${ }^{3}$} \\
\hline $\mathrm{g} / 100 \mathrm{~g}$ of milk & 1.45 & 1.51 & 0.02 & 0.04 \\
\hline $\mathrm{g} / 100 \mathrm{~g}$ of fatty acids & 35.53 & 38.31 & 0.31 & $<0.01$ \\
\hline $\mathrm{g} / \mathrm{d}$ & 376.4 & 333.4 & 19.2 & 0.12 \\
\hline MUN, mg/dL & 11.4 & 11.3 & 0.5 & 0.89 \\
\hline Anhydrous lactose, \% & 4.60 & 4.59 & 0.02 & 0.66 \\
\hline Anhydrous lactose, $\mathrm{kg} / \mathrm{d}$ & 1.22 & 1.05 & 0.06 & 0.07 \\
\hline
\end{tabular}


Table 8. Effects of feed additives included in TMR on high de novo (HDN; $n=15$ ) or low de novo (LDN; $n$ =18) farms sampled during the farm visit

\begin{tabular}{lcccc}
\hline Item & HDN, $\%$ & LDN, $\%$ & OR $^{1}(95 \%$ CI $)$ & $P$-value \\
\hline Animal-derived fat & $19.93^{2}$ & $38.84^{2}$ & $0.39(0.07-2.14)$ & 0.27 \\
Rumen-inert fat & 6.64 & 33.26 & $0.13(0.01-1.55)$ & 0.11 \\
Monensin $^{3}$ & 46.65 & 44.42 & $1.09(0.25-4.82)$ & 0.90 \\
Yeast $^{4}$ & 6.66 & 10.99 & $0.57(0.04-8.28)$ & 0.67 \\
Animal-derived protein $_{\text {Commercial AA }}$ & 33.27 & 38.84 & $0.79(0.17-3.67)$ & 0.75 \\
Dried distillers grain & 13.28 & 33.26 & $0.31(0.05-2.06)$ & 0.22 \\
\hline
\end{tabular}

${ }^{1} \mathrm{OR}=$ odds ratio. The HDN group was set as referent.

${ }^{2}$ Percentage of farms feeding product.

${ }^{3}$ Rumensin, Elanco Animal Health, Indianapolis, IN.

${ }^{4}$ Live and cultured yeast products.

(expressed as $\mathrm{g} / 100 \mathrm{~g}$ of $\mathrm{FA}$ ) were a result of increased de novo FA yield and not because cows on LDN farms were yielding more preformed FA per day.

\section{Management Practices}

Stall stocking density was lower $(P=0.05$; Table 9) on HDN farms and bunk space was numerically higher on HDN farms but no significant difference was detected $(P=0.13$; Table 9$)$. Stall stocking density above one cow per stall often reduces the time cows spend lying and ruminating (Batchelder, 2000; Grant and Albright, 2001) and alters feeding behavior such that the rate of eating increases, with fewer, larger meals being consumed. Krawczel et al. (2012) reported an increase in feed bunk aggression and a decrease in lying time when cows were housed at 1.42 compared with 1.00 stall and headlock per cow. Altered feeding behavior at higher stall and feedbunk stocking densities may predispose the cow to SARA, and Campbell et al. (2015) reported that mean ruminal $\mathrm{pH}$ and the time below a $\mathrm{pH}$ of 5.8 increased when cows were stocked at 1.42 compared with 1.00 stalls and headlocks per cow. Furthermore, Hill et al. (2007) reported a 0.2 reduction in milk fat percentage (mass/mass) when cows were housed at 1.42 cows per stall and headlock compared with $1.00(P=0.03)$, presumably due to changes in ruminal conditions.

The current study did not detect a significant difference in bunk space per cow between HDN and LDN farms; however, Sova et al. (2013) reported that a $10-\mathrm{cm} / \mathrm{cow}$ increase in feed bunk space was associated with a 0.06 increase in milk fat percentage (mass/ mass). Compared with access to freestalls, bunk space is the first limiting resource in 3-row pens; however, in the current study no difference was detected in the odds for HDN farms to have pens that contain 3 rows versus 2 rows of freestalls $(P=0.28$; Table 5$)$, so the pen design was not likely to confound these results.

High de novo tiestall farms fed their cows more frequently compared with the LDN farms $(P=0.05$; Table $9)$. Fourteen of the 21 tiestall farms fed a componentbased diet (grain and forages fed separately). When grain is fed separately, it is often consumed rapidly (Robinson, 1989), which has been found to decrease ruminal pH (Bauman and Griinari, 2003; Bradford and Allen, 2004) and is correlated with a decrease in milk fat content (Allen, 1997). However, more frequent delivery

Table 9. Least squares means of management factors for high de novo (HDN) or low de novo (LDN) farms observed or recorded during the farm visit. Percentage of Holsteins was included in the model as a covariate when $P<0.05$

\begin{tabular}{lcccc}
\hline Item & HDN & LDN & SEM & $P$-value \\
\hline Cows milking, ${ }^{1}$ no. & 105 & 108 & 19 & 0.93 \\
DIM & 165 & 179 & 36.4 & 0.88 \\
Bunkspace, $^{1,2} \mathrm{~cm} /$ cow $^{2}$ cow/stall & 50.6 & 42.4 & 3.6 & 0.13 \\
Stall stocking density, $^{2}$ Tiestall feeding frequency per day & 1.05 & 1.20 & 0.05 & 0.05 \\
Feed push-up frequency per day & 4.6 & 2.9 & 0.7 & 0.05 \\
Tiestall & & & & \\
Freestall & 1.3 & 3.5 & 0.9 & 0.06 \\
BCS & 2.7 & 4.8 & 0.9 & 0.10 \\
\hline
\end{tabular}

${ }^{1}$ Covariate adjusted means.

${ }^{2}$ Only applicable to farms with freestall-housed lactating cows $(\mathrm{n}=23)$. 
Table 10. Nutritional characteristics of weighted average of TMR from high de novo (HDN) and low de novo (LDN) farms

\begin{tabular}{lrccc}
\hline Item & HDN & LDN & SEM & $P$-value \\
\hline DM, \% & 42.2 & 38.9 & 2.1 & 0.24 \\
CP, \% of DM & 15.1 & 16.0 & 0.6 & 0.24 \\
ADF, \% of DM & 22.7 & 23.7 & 1.1 & 0.50 \\
NDF, \% of DM & 37.4 & 38.7 & 1.4 & 0.48 \\
Starch, \% of DM & 23.1 & 20.2 & 1.5 & 0.15 \\
Ether extract, \% of DM & 3.7 & 4.4 & 0.1 & $<0.01$ \\
Ash, \% of DM & 8.3 & 8.9 & 0.4 & 0.24 \\
Forage, \% DM & 58.1 & 57.8 & 0.1 & 0.51 \\
\hline
\end{tabular}

of concentrate feeds, as was observed on HDN farms in the current study, can help to prevent postprandial decreases in ruminal pH (French and Kennelly, 1990).

All freestall farms on this study fed a TMR either once or twice a day. No difference was detected in feed delivery frequency between HDN and LDN freestall farms $(P>0.10$; Table 9$)$. Previous research supports that feeding cows more frequently promotes more natural feeding behavior (DeVries et al., 2005), reduces sorting (DeVries et al., 2008), and is associated with increased milk fat content (Rottman et al., 2014; Sova et al., 2013). Sorting against long particles can result in a reduced ruminal $\mathrm{pH}$ (DeVries et al., 2008), potentially increasing the cow's risk for milk fat depression (Allen, 1997; Bauman et al., 2006). To our knowledge, the current study is the first to evaluate the effects of feed delivery on milk FA profiles.

Interestingly, LDN tiestall and freestall farms tended ( $P=0.06$ and 0.10 , respectively) to push up the feed more frequently than HDN farms (Table 6). This unexpected result may have been a function of reduced feeding frequency (Table 6) for LDN tiestall farms, because when feed is delivered less often it must be pushed up more frequently to provide the cow with physical access to the feed. Practices that increase feed availability, such as feed delivery or feed push up, increase feed bunk attendance (DeVries et al., 2003). However, DeVries and von Keyserlingk (2005) found that cows are more motivated to eat by fresh feed delivery than they are by simply pushing up previously delivered feed.

Body condition score was lower on LDN farms $(P$ $=0.002 ;$ Table 10), although the relative difference between the groups was small (2.96 vs. 3.08 for LDN vs. HDN, respectively). The LDN farms had higher preformed FA (expressed as g/100 $\mathrm{g}$ of FA and as g/100 $\mathrm{g}$ of milk) and lower milk yield compared with HDN farms (Table 7), suggesting that perhaps LDN farms were mobilizing more adipose tissue due to insufficient energy intake. Many LDN farms had extremely underconditioned cows (the range in BCS by farm was 2.65 to 3.12 for LDN farms versus 2.89 to 3.41 for HDN herds). Due to insufficient quality or quantity of feed, cows may experience negative energy balance in mid or late lactation (Leiber et al., 2005).

\section{Dietary Strategies}

This study relied on NIRS prediction of the chemical composition of forages and TMR. The use of NIRS methods to predict the chemical composition of forages is well accepted, although its use with TMR is less well investigated. However, Berghazi et al. (2000) used an NIRS approach commonly employed in forage testing laboratories (use of a local algorithm) and found that basic chemical fractions of TMR can be accurately predicted. Additionally, Mentink et al. (2006) reported good to moderate utility of NIRS methods to predict the $\mathrm{CP}, \mathrm{NDF}$, starch, and fat content $\left(\mathrm{R}^{2} \geq 0.81\right)$ of TMR. In this initial study, we concluded that the accuracy of NIRS for predicting TMR chemical composition was sufficient to allow us to identify important dietary fractions for more intensive future research that would rely on wet chemistry analyses.

No differences were detected in DM, CP, NDF, ADF, starch, ash, or percentage of forage in the diet from HDN and LDN farms $(P>0.10$; Table 10). However, ether extract (EE) content was lower in diets for HDN farms $(P<0.01$; Table 10). The relationship between dietary fat and milk fat composition has been reviewed previously (Bauman and Griinari, 2003; Bauman et al., 2006; Harvatine et al., 2009), and excessive levels of dietary fat are a risk factor for milk fat depression. However, a typical EE content for a high-producing dairy cow diet is around 4 to $5 \%$ of DM (NRC, 2001) and the EE for HDN and LDN farms was 3.7 and $4.4 \%$ of DM, respectively $(P<0.01$; Table 10$)$. It was not expected that this dietary content of EE would have an effect on de novo FA synthesis. Further analysis would be needed to understand the composition of the FA that are measured using EE, and whether it contained PUFA that, combined with other dietary and management factors, may have caused a shift in the biohydrogenation pathway that reduced de novo FA synthesis on the LDN farms (Bauman and Griinari, 2003). 
Table 11. Nutritional characteristics for high de novo (HDN) and low de novo (LDN) farms for hay crop silage $(\mathrm{n}=19 \mathrm{HDN} ; \mathrm{n}=20 \mathrm{LDN})$ and corn silage $(\mathrm{n}=15 \mathrm{HDN} ; \mathrm{n}=12 \mathrm{LDN})$ sampled during the farm visit

\begin{tabular}{|c|c|c|c|c|}
\hline Item & $\mathrm{HDN}$ & $\mathrm{LDN}$ & SEM & $P$-value \\
\hline \multicolumn{5}{|l|}{ Hay crop silage } \\
\hline DM, $\%$ of as fed & 43.7 & 37.8 & 3.4 & 0.21 \\
\hline $\mathrm{CP}, \%$ of $\mathrm{DM}$ & 16.1 & 16.5 & 0.7 & 0.75 \\
\hline $\mathrm{ADF}, \%$ of $\mathrm{DM}$ & 35.4 & 36.5 & 0.8 & 0.35 \\
\hline NDF, $\%$ of DM & 55.5 & 55.7 & 1.3 & 0.91 \\
\hline $\mathrm{ESC}, 1 \%$ of DM & 6.0 & 5.9 & 1.0 & 0.96 \\
\hline Ether extract, $\%$ of DM & 4.4 & 4.3 & 0.2 & 0.83 \\
\hline Ash, \% of DM & 9.1 & 10.3 & 0.3 & 0.02 \\
\hline \multicolumn{5}{|l|}{ Corn silage } \\
\hline DM, $\%$ of as fed & 32.6 & 29.8 & 1.2 & 0.10 \\
\hline CP. $\%$ of $\mathrm{DM}$ & 7.9 & 8.2 & 0.2 & 0.25 \\
\hline $\mathrm{ADF}, \%$ of $\mathrm{DM}$ & 25.2 & 25.7 & 0.8 & 0.62 \\
\hline $\mathrm{NDF}, \%$ of DM & 42.9 & 43.2 & 1.1 & 0.86 \\
\hline ESC, $\%$ of DM & 1.7 & 1.9 & 0.1 & 0.36 \\
\hline Ether extract, $\%$ of DM & 3.2 & 3.4 & 0.1 & 0.31 \\
\hline Starch, $\%$ of DM & 32.5 & 31.4 & 1.4 & 0.55 \\
\hline Ash, $\%$ of DM & 3.7 & 4.0 & 0.2 & 0.41 \\
\hline
\end{tabular}

${ }^{1} \mathrm{ESC}=$ ethanol-soluble carbohydrates.

No differences in the chemical composition of forages from HDN and LDN farms were detected $(P>0.10)$ with the exception of a higher ash content of hay crop silages on LDN farms (Table 11). This may have been as a result of harvesting equipment used on LDN farms or other management factors. Higher ash content may cause a poor fermentation in hay crop silage (Kung et al., 2015), which will affect rumen conditions; however, the ash content of the TMR was not different between HDN and LDN farms. Therefore, it was unlikely that the higher ash content of hay crop silages for LDN farms was affecting de novo FA synthesis.

\section{Supplemental Feed Products}

Feed additives and supplements such as distillers grains (Schingoethe et al., 2009), monensin (Duffield et al., 2008), rumen-inert fat (Loften et al., 2014), animalderived fat (Onetti et al., 2003), yeast (Desnoyers et al., 2009), and EAA (Zanton et al., 2014) may affect milk fat content, yield, and composition. However, the current study found no relationship of milk de novo FA with feed additives $(P>0.10$; Table 8$)$. The percentage of LDN farms feeding commercial, rumen-inert fat products was numerically higher, but no significant difference was detected (6.6 vs. $33.2 \%$ of farms for HDN vs. LDN, respectively; $P=0.11$ ).

\section{CONCLUSIONS}

To our knowledge, the current study is the first to evaluate the relationship of management, dietary composition, and lactation performance with de novo milk FA content and yield on commercial dairies with high- and low-bulk tank de novo milk FA content. The current study identified management practices, such as higher stall stocking density and lower feeding frequency, which were related to lower de novo FA content in bulk tank milk. Farms with lower de novo FA, on average, produced less milk fat and protein per cow per day. In addition, higher dietary EE was related to lower de novo FA content of milk, although more work using wet chemistry methods is required to better understand the effect of dietary fat on bulk tank milk FA. High de novo farms also had higher milk yield and fat and true protein content and yield. However, the current study was conducted on primarily small- and medium-sized farms with a relatively low milk production average. Therefore, a need exists for future research on larger, higher-producing commercial farms to verify the relationships between diet and management, de novo FA synthesis, bulk tank milk composition, and lactation performance.

\section{ACKNOWLEDGMENTS}

The authors thank the laboratory and field staff of St. Albans Cooperative Creamery (St. Albans, VT) for their technical assistance in milk analysis and farm visits. In addition, the authors are grateful for the assistance of the farms who participated on this study. The technical support of Evert De Jong and Wopke Boekema of Delta Instruments (Drachten, the Netherlands) was important for this study. The laboratory analysis support for milk reference chemistry by Sara Bova, Michelle Bilotta, Chassidy Coon, and Karen Wojciechowski (Department of Animal Science, Cornell University, Ithaca, NY) is greatly appreciated as is the 
support from Miner Institute (Chazy, NY) research staff.

\section{REFERENCES}

Akaike, H. 1973. Information theory and an extension of the maximum likelihood principle. Pages 267-281 in Second International Symposium on Information Theory. B. N. Petrov and F. Csaki, ed. Academia Kaido, Budapest, Hungary.

Allen, M. S. 1997. Relationship between fermentation acid production in the rumen and the requirement for physically effective fiber. J. Dairy Sci. 80:1447-1462.

AOAC International. 2000. Official Methods of Analysis 17th ed AOAC International, Arlington, VA.

AOAC International. 2012. Official Methods of Analysis 19th ed. AOAC International, Arlington, VA.

Bach Knudsen, K. E. 1997. Carbohydrate and lignin contents of plant materials used in animal feeding. Anim. Feed Sci. Technol. 67:319 338

Bailey, K. W., C. M. Jones, and A. J. Heinrichs. 2005. Economic returns to Holstein and Jersey farms under multiple component pricing. J. Dairy Sci. 88:2269-2280.

Barbano, D. M., C. Melilli, and T. R. Overton. 2014. Advanced use of FTIR spectra of milk for feeding and health management. Pages 105-113 in Proc. Cornell Nutrition Conf., Syracuse, NY. Cornell University, Ithaca, NY.

Batchelder, T. L. 2000. The impact of head gates and overcrowding on production and behavior patterns of lactating dairy cows. Pages 325-330 in Dairy Housing and Equipment Systems. Managing and Planning for Profitability. Natural Resource, Agriculture, and Engineering Service, Camp Hill, PA

Bauman, D. E., and J. M. Griinari. 2003. Nutritional regulation of milk fat synthesis. Annu. Rev. Nutr. 23:203-227.

Bauman, D. E., I. H. Mather, R. J. Wall, and A. L. Lock. 2006. Major advances associated with the biosynthesis of milk. J. Dairy Sci 89:1235-1243

Berghazi, P., J. S. Shenk, and M. O. Westerhaus. 2000. LOCAL prediction with near infrared multi-purpose databases. J. Near Infrared Spectrosc. 8:1-9.

Bradford, B. J., and M. S. Allen. 2004. Milk fat response to a change in diet fermentability vary by production level in dairy cattle. J. Dairy Sci. 87:3800-3807.

Campbell, M. A., K. W. Cotanch, C. S. Ballard, H. M. Dann, D. M Barbano, A. M. Couse, and R. J. Grant. 2015. Effects of stocking density and source of forage fiber on short-term behavioral and lactational responses of Holstein dairy cows. J. Dairy Sci. 98(E Suppl. 2):18. (Abstr.)

Cody, R. 2011. SAS Statistics by Example. SAS Institute Inc., Cary, $\mathrm{NC}$

Coppa, M., A. Ferlay, C. Chassaing, C. Agabriel, F. Glasser, Y. Chilliard, G. Borreani, T. Baars, D. Kusche, O. M. Harstad, J. Verbic, J. Golecký, and B. Marin. 2013. Prediction of bulk milk fatty acid composition based on farming practices collected through on-farm surveys. J. Dairy Sci. 96:4197-4211.

Desnoyers, M., S. Giger-Reverdin, G. Bertin, C. Duvaux-Ponter, and D. Sauvant. 2009. Meta-analysis of the influence of Saccharomyces cerevisiae supplementation on ruminal parameters and milk production of ruminants. J. Dairy Sci. 92:1620-1632.

DeVries, T. J., F. Dohme, and K. A. Beauchemin. 2008. Repeated ruminal acidosis challenges in lactating dairy cows at high and low risk for developing acidosis: Feed sorting. J. Dairy Sci. 91:3958 3967

DeVries, T. J., and M. A. G. von Keyserlingk. 2005. Time of feed delivery affects the feeding and lying patterns of dairy cows. J. Dairy Sci. 88:625-631.

DeVries, T. J., M. A. G. von Keyserlingk, and K. A. Beauchemin 2003. Short communication: Diurnal feeding pattern of lactating dairy cows. J. Dairy Sci. 86:4079-4082.
DeVries, T. J., M. A. G. von Keyserlingk, and K. A. Beauchemin. 2005. Frequency of feed delivery affects the behavior of lactating dairy cows. J. Dairy Sci. 88:3553-3562.

Duffield, T. F., A. R. Rabiee, and I. J. Lean. 2008. A meta-analysis of the impact of monensin in lactating dairy cattle, part 2. Production effects. J. Dairy Sci. 91:1347-1360.

Ferguson, J. D., D. T. Galligan, and N. Thomsen. 1994. Principal descriptors of body condition scores in Holstein cattle. J. Dairy Sci. 77:2695-2703.

French, N., and J. J. Kennelly. 1990. Effects of feeding frequency on ruminal parameters, plasma insulin, milk yield, and milk composition in Holstein cows. J. Dairy Sci. 73:1857-1863.

Gbur, E. E., W. W. Stroup, K. S. McCarter, S. Durham, L. J. Young, M. Christman, M. West, and M. Kramer. 2012. Generalized linear mixed models. Pages 109-184 in Analysis of Generalized Linear Mixed Models in the Agricultural and Natural Resources Sciences. American Society of Agronomy, Madison, WI.

Grant, R. J., and J. L. Albright. 2001. Effect of animal grouping on feeding behavior and intake of cattle. J. Dairy Sci. 84(Suppl.):E156E163.

Grummer, R. R. 1991. Effect of feed on the composition of milk fat. J. Dairy Sci. 74:3244-3257.

Harvatine, K. J., and D. E. Bauman. 2011. Characterization of the acute lactational response to trans-10,cis-12 conjugated linoleic acid. J. Dairy Sci. 94:6047-6056.

Harvatine, K. J., Y. R. Boisclair, and D. E. Bauman. 2009. Recent advances in the regulation of milk fat synthesis. Animal 3:40-54.

Hill, C. T., P. D. Krawczel, H. M. Dann, C. S. Ballard, R. C. Hovey, and R. J. Grant. 2007. Effect of stocking density on the short-term behavior of dairy cows. J. Dairy Sci. 90(Suppl. 1):244.

Jensen, R. G. 2002. The composition of bovine milk lipids: January 1995 to December 2000. J. Dairy Sci. 85:295-350.

Kaylegian, K. E., D. A. Dwyer, J. M. Lynch, D. E. Bauman, J. R. Fleming, and D. M. Barbano. 2009b. Impact of fatty acid composition on the accuracy of mid-infrared fat analysis of farm milks. J. Dairy Sci. 92:2502-2513.

Kaylegian, K. E., G. E. Houghton, J. M. Lynch, J. R. Fleming, and D. M. Barbano. 2006. Calibration of infrared milk analyzers: Modified milk versus producer milk. J. Dairy Sci. 89:2817-2832.

Kaylegian, K. E., J. M. Lynch, J. R. Fleming, and D. M. Barbano. 2009a. Influence of fatty acid chain length and unsaturation on mid infrared milk analysis. J. Dairy Sci. 92:2485-2501.

Krawczel, P. D., L. B. Klaiber, R. E. Butzler, L. M. Klaiber, H. M. Dann, C. S. Mooney, and R. J. Grant. 2012. Short-term increases in stocking density affect the lying and social behavior, but not the productivity, of lactating Holstein dairy cows. J. Dairy Sci. 95:4298-4308

Kung, L., J. M. Lim, D. J. Hudson, J. M. Smith, and R. D. Joerger. 2015. Chemical composition and nutritive value of corn silage harvested in the northeastern Unites States after Tropical Storm Irene. J. Dairy Sci. 98:2055-2062.

Leiber, F., M. Kreuzer, D. Nigg, H. R. Wettstein, and M. R. L. Scheeder. 2005. A study on the causes for the elevated n-3 FA in cows milk from alpine origin. Lipids 40:191-202.

Loften, J. R., J. G. Linn, J. K. Drackley, T. C. Jenkins, C. G. Soderholm, and A. F. Kertz. 2014. Invited review: Palmitic and steric acid metabolism in lactating dairy cows. J. Dairy Sci. 97:4661 4674 .

Lynch, J. M., D. M. Barbano, and D. E. Bauman. 1992. Effect of a prolonged-release formulation of n-methionyl bovine somatrotropin (Sometribove) on milk fat. J. Dairy Sci. 75:1794-1809.

Lynch, J. M., A. L. Lock, D. A. Dwyer, R. Noorbakhsh, D. M. Barbano, and D. E. Bauman. 2005. Flavor and stability of pasteurized milk with elevated levels of conjugated linoleic acid and vaccenic acid. J. Dairy Sci. 88:489-498.

Maurice-Van Eijndhoven, M. H. T., H. Soyeurt, F. Dehareng, and M. P. L. Calus. 2013. Validation of fatty acid predictions in milk using mid-infrared spectrometry across cattle breeds. Animal 7:348-354.

Mentink, R. L., P. C. Hoffman, and L. M. Bauman. 2006. Utility of near-infrared reflectance spectroscopy to predict nutrient composi- 
tion and in vitro digestibility of total mixed rations. J. Dairy Sci. 89:2320-2326.

NRC. 2001. Nutrient Requirements of Dairy Cattle. 7th rev. ed. Natl. Acad. Press, Washington, DC

Neville, M. C., and M. F. Picciano. 1997. Regulation of milk lipid secretion and composition. Annu. Rev. Nutr. 17:159-183.

Onetti, S. G., R. D. Shaver, S. J. Bertics, and R. R. Grummer. 2003. Influence of corn silage particle length on the performance of lactating dairy cows fed supplemental tallow. J. Dairy Sci. 86:29492957.

Palmquist, D. L., A. D. Beaulieu, and D. M. Barbano. 1993. Feed and animal factors influencing milk fat composition. J. Dairy Sci. $76: 1753-1771$.

Robinson, P. H. 1989. Dynamic aspects of feeding management for dairy cows. J. Dairy Sci. 72:1197-1209.

Rottman, L. W., Y. Ying, K. Zhou, P. A. Bartell, and K. J. Harvatine 2014. The daily rhythm of milk synthesis is dependent on the timing of feed intake in dairy cows. Physiol. Rep. 2:e12049.

Schingoethe, D. J., K. F. Kalscheur, A. R. Hippen, and A. D. Garcia 2009. Invited review: The use of distillers products in dairy cattle diets. J. Dairy Sci. 92:5802-5813.

Shenk, J. S., and M. O. Westerhaus. 1991. Population definition, sample selection, and calibration procedures for near infrared reflectance spectroscopy. Crop Sci. 31:469-474.

Silva, P. R. B., A. R. Dresch, D. S. Machado, J. G. N. Moraes, K Lobeck-Luchterhand, T. K. Nishimura, M. A. Ferreira, M. I. Endres, and R. C. Chebel. 2014. Prepartum stocking density: Effects on metabolic health, reproductive, and productive responses. J. Dairy Sci. 97:5521-5532.

Sova, A. D., S. J. LeBlanc, B. W. McBride, and T. J. DeVries. 2013 Associations between farm-level feeding management practices, feed sorting, and milk production in freestall dairy farms. J. Dairy Sci. 96:4759-4770.
Soyeurt, H., P. Dardenn, A. Gillon, C. Croquet, S. Vanderick, P. Mayeres, C. Bertozzi, and N. Gengler. 2006. Variation of fatty acid contents of milk and milk fat within and across breeds. J. Dairy Sci. 89:4858-4865.

Soyeurt, H., F. Dehareng, N. Gengler, S. McParland, E. Wall, D. P. Berry, M. Coffey, and P. Dardenne. 2011. Mid-infrared prediction of bovine milk fatty acids across multiple breeds, production systems, and countries. J. Dairy Sci. 94:1657-1667.

Stoffel, C. M., P. M. Crump, and L. E. Armentano. 2015. Effect of dietary FA supplements, varying in FA composition, on milk fat secretion in dairy cattle fed diets supplemented to less than $3 \%$ total FA. J. Dairy Sci. 98:431-442.

Stoop, W. M., H. Bovehuis, J. M. Heck, and J. A. van Arendonk. 2009. Effect of lactation stage and energy status on milk fat composition of Holstein-Friesian cows. J. Dairy Sci. 92:1469-1478.

Toral, P. G., L. Bernard, Y. Chilliard, and F. Glasser. 2013. Short communication: Diet-induced variations in milk fatty acid composition have minor effects on the estimated melting point of milk fat in cows, goats, and ewes: Insights from a meta-analysis. J. Dairy Sci. 96:1232-1236.

USDA. 2014. Northeast Order Uniform Price for 2014: Monthly Price Releases. Federal Milk Market Administrator. Accessed Jul. 25, 2016. http://www.fmmone.com/Uniform_Price_Release/Past_ Years/nr2014.pdf.

Wojciechowski, K. L., C. Melilli, and D. M. Barbano. 2016. A proficiency test system to improve performance of milk analysis methods and produce reference values for component calibration samples for infrared milk analysis. J. Dairy Sci. 99:6808-6827.

Zanton, G. I., G. R. Bowman, M. Vázquez-Añón, and L. M. Rode. 2014. Meta-analysis of lactation performance in dairy cows receiving supplemental dietary methionine sources or postruminal infusion of methionine. J. Dairy Sci. 97:7085-7101. 